\title{
Articulo Original / Original Article \\ Pharmacobotanical characterization of Monteverdia ilicifolia (Mart. ex Reiss.) Biral leaves and its adulterants sold as medicinal tea in Brazil: a contribution to quality control
}

[Caracterización farmacobotánica de hojas de Monteverdia ilicifolia (Mart. ex Reiss.) Biral y sus adulterantes vendidos como té medicinal en Brasil: una contribución al control de calidad]

Fernanda Moreira do Amaral ${ }^{1,2}$, Sarah de Sá Rego Monteiro, ${ }^{1,3}$, Thiago Fernandes ${ }^{1,4}$, Dulcinéia Furtado Teixeira ${ }^{5,6}$, Leonardo Lucchetti ${ }^{6}$, Silvana do Couto Jacob ${ }^{5}$, Selma Ribeiro de Paiva ${ }^{1} \&$ Ana Joffily ${ }^{1}$

\author{
${ }^{1}$ Instituto de Biologia, Universidade Federal Fluminense, Niterói, Brasil \\ ${ }^{2}$ Programa de Pós-Graduação em Ciências Biológicas, Universidade Federal do Rio de Janeiro, Rio de Janeiro, Brasil \\ ${ }^{3}$ Curso de Graduação em Ciências Biológicas, Faculdades Integradas Maria Thereza, Niterói, Brasil \\ ${ }^{4}$ Instituto de Pesquisas Jardim Botânico do Rio de Janeiro, Rio de Janeiro, Brasil \\ ${ }^{5}$ Programa de Pós-Graduação em Vigilância Sanitária (INCQS), Fundação Oswaldo Cruz, Rio de Janeiro, Brasil \\ ${ }^{6}$ Fundação Oswaldo Cruz, Rio de Janeiro, Brasil
}

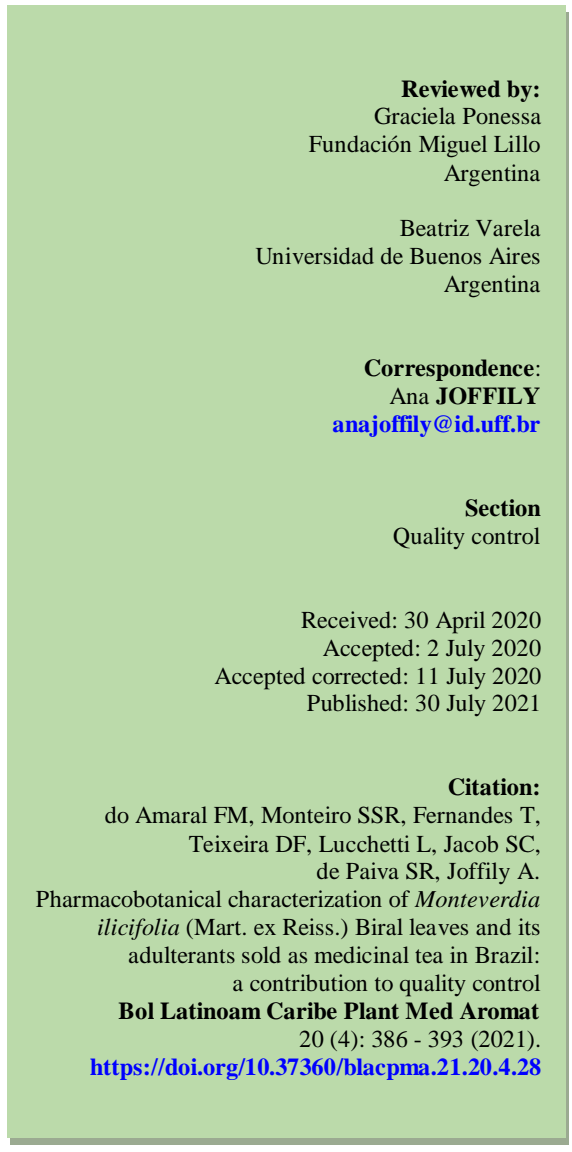

Abstract: Leaves of Monteverdia ilicifolia ("espinheira-santa") are considered a medicinal tea by the Brazilian Sanitary Surveillance Agency (Anvisa), by their anti-dyspeptic, anti-acid and protective of the gastric mucosa properties. Their spiny margins are similar to those of other botanical species, which may lead to misidentifications. The aim of this work was to evaluate the authenticity of 32 samples of herbal drugs commercialized as "espinheira-santa" in the formal trade in Brazil, by macro and microscopic morphological studies of the leaves. The evaluation of the botanical authenticity was based on leaf venation patterns, shape and anatomy of the petiole and midrib region in cross section, vascular system arrangement and epidermal characters. Analysis of these characters compared to literature data suggests that $34 \%$ of the samples are M. ilicifolia and the remaining $66 \%$ are Sorocea bonplandii, a species with no clinical studies assuring its effective and safe use, representing thus a potential risk to public health.

Keywords: Adulteration; Falsification; Espinheira-santa; Plant anatomy; Sorocea.

Resumen: Las hojas de Monteverdia ilicifolia ("espinheira-santa") son consideradas tés medicinales por la Agencia Nacional de Vigilancia Sanitaria (Anvisa), Brasil, por las indicaciones terapéuticas como antidispépticos, antiácidos y protectores de la mucosa gástrica. Sus márgenes foliares espinescentes se parecen a los de otras especies, conduciendo a identificaciones erróneas. El objetivo de este trabajo fue evaluar la autenticidad de 32 muestras de drogas vegetales vendidas como "espinheira-santa" en el comercio legal de Brasil, realizando un estudio morfológico de las hojas. Esta evaluación se ha basado en observar de la hoja, sus patrones de nerviación, su forma y anatomía (pecíolo y nervadura central en corte transversal), disposición del sistema vascular y caracteres epidérmicos. El análisis de la morfología, comparado con los datos de literatura, sugiere que el 34\% de las muestras son M. ilicifolia y el $66 \%$ son Sorocea bonplandii, una especie que no cuenta con los estudios clínicos que garantizan su uso efectivo y seguro, representando un riesgo para la salud pública.

Palabras clave: Adulteración; Falsificación; Espinheira-santa; Anatomía vegetal; Sorocea. 


\section{INTRODUCTION}

Monteverdia ilicifolia (Mart. ex Reiss.) Biral (basionym: Maytenus ilicifolia Mart. ex Reiss.) (Celastraceae) is native from Brazil (Lombardi et al., 2015; Biral et al., 2017) and included in the Form of Phytotherapeutics of the Brazilian Pharmacopoeia with the vernacular name "espinheira-santa" (holythorn) (Brazil, 2011). The preparation of its dried leaves by infusion is associated with therapeutic indications such as anti-dyspeptic, anti-acid and protective of the gastric mucosa, corroborating its large use in traditional medicine (Scheffer, 2004). Accordingly, this herbal drug is officially regarded as a medicinal tea and, prior the commercialization, should be notified by the producers to the Brazilian Sanitary Surveillance Agency (Anvisa) in the category of traditional phytotherapeutic product (Brazil, 2011; Brazil, 2014a; Brazil, 2014b; Brazil, 2019). In addition, this botanical species is included in the Brazilian List of Medicinal Plants of Interest to the Public Health System - SUS (Brazil, 2009).

The leaves displaying spiny teeth along the margin in Monteverdia ilicifolia are similar to those of other botanical species, such as Sorocea bonplandii (Baill.) W.C. Burger, Lanj. \& Wess. Boer (Moraceae) and Zollernia ilicifolia (Brongn.) Vogel (Fabaceae) (Machado \& Santos, 2004), leading to the occurrence of adulterations and falsifications, which are usually verified by macroscopic morphological (Coulaud-Cunha et al., 2004; Leitão et al., 2009) or chemical analysis (Preto et al., 2013; Teixeira et al., 2018). In relation to the latter, the morphological study has the advantage that it can be carried out with simple, fast and easy techniques of low cost, although it relies heavily on the expertise of the Botany professional who carries out the inspection of samples (Zhao et al., 2006; Santos et al., 2015).

The macroscopic morphological evaluation of the botanical identity of samples marketed as "espinheira-santa" contributes to a safe access to the medicinal tea by the population (Coulaud-Cunha et al., 2004; Leitão et al., 2009), but faces difficulties related to the fact that this product is often present in the form of leaf fragments (Teixeira et al., 2018). In this context, plant anatomy represents a very useful tool for the botanical identification of fragmented material, contributing to the quality control of medicinal plants (Aoyama \& Indriunas, 2015). Nevertheless, the authenticity evaluation of "espinheira-santa" by anatomical analysis available in literature shows mostly general descriptions and documentation (Chimin et al., 2008; Costa et al., 2014; Leal-Costa et al., 2018).
Under those circumstances, the aim of this work was to evaluate the authenticity of commercial samples marketed as "espinheira-santa" in Brazil, by macro and microscopic morphological studies of the leaves.

\section{MATERIAL AND METHODS}

Thirty-two samples of "espinheira-santa" in a dry fragmented form were purchased from the formal trade in Rio de Janeiro state, Brazil, between 2014 and 2016. Voucher specimens were deposited in the Herbarium NIT, of Universidade Federal Fluminense, Niterói, Rio de Janeiro, Brazil (23 specimens), and the Herbarium HUSC, of Universidade Santa Cecília, Santos, São Paulo, Brazil (9 specimens), with the accession numbers: NITe1 to NITe23 (in sequence), and HUSC-11947 to HUSC-11955 (in sequence).

For the venation pattern analysis, the leaves were submitted to diaphanization (Shobe \& Lersten, 1967). Three fragments of each sample were hydrated in $5 \%$ sodium hydroxide in an oven at $60^{\circ} \mathrm{C}$, changing the solution three times, until the completion of bleaching. Then, they were placed in chloral hydrate until becoming transparent and then stained with aqueous Safranin for the preparation of semi-permanent slides, which were further analyzed and photographed using a Sony Cybershot DSC-W90 camera fitted to an Olympus SZX12 stereomicroscope. The venation patterns were described based on Hickey (1973).

For the anatomical study, the leaves were hydrated and softening in distilled water, being kept sealed in an oven at $60^{\circ} \mathrm{C}$ for, at least, three days. Hand-made cross sections were obtained on the petiole (when present in the sample) and midrib of a minimum of three leaves per sample, which were clarified and neutralized in solutions of $50 \%$ sodium hypochlorite and $1 \%$ acetic acid and stained with a Safranin-Astra Blue combination at the proportion of 9:1 (Kraus \& Arduin, 1997) for the preparation of semi-permanent slides to be further analyzed and photomicrographed using a Zeiss AxioCam ERc 5s camera fitted to a Zeiss Primo Star optical microscope.

The morphological descriptions were compared with specific literature data (Jacomassi \& Machado, 2003; Machado \& Santos, 2004; Duarte \& Debur, 2005; Brazil, 2019) to assess the botanical authenticity of the samples.

\section{RESULTS}

In all samples, the secondary veins terminate at the margin, determining the craspedodromous pattern 
(Figure No. 1a and Figure No. 1b). Two groups of samples could be identified as two different patterns were observed. The leaves of 11 samples (34\%), grouped as I, were simple craspedodromous because all secondary veins and their respective branches end at the margin (Figure No. 1a). Differently, in other 21 samples $(66 \%)$, grouped as II, the leaves were semicraspedodromous, because the secondary veins branch within the margin, with a branch ending at the margin and the other connecting to the super-adjacent secondary (Figure No. 1b). Secondary veins were more prominent in samples of group II
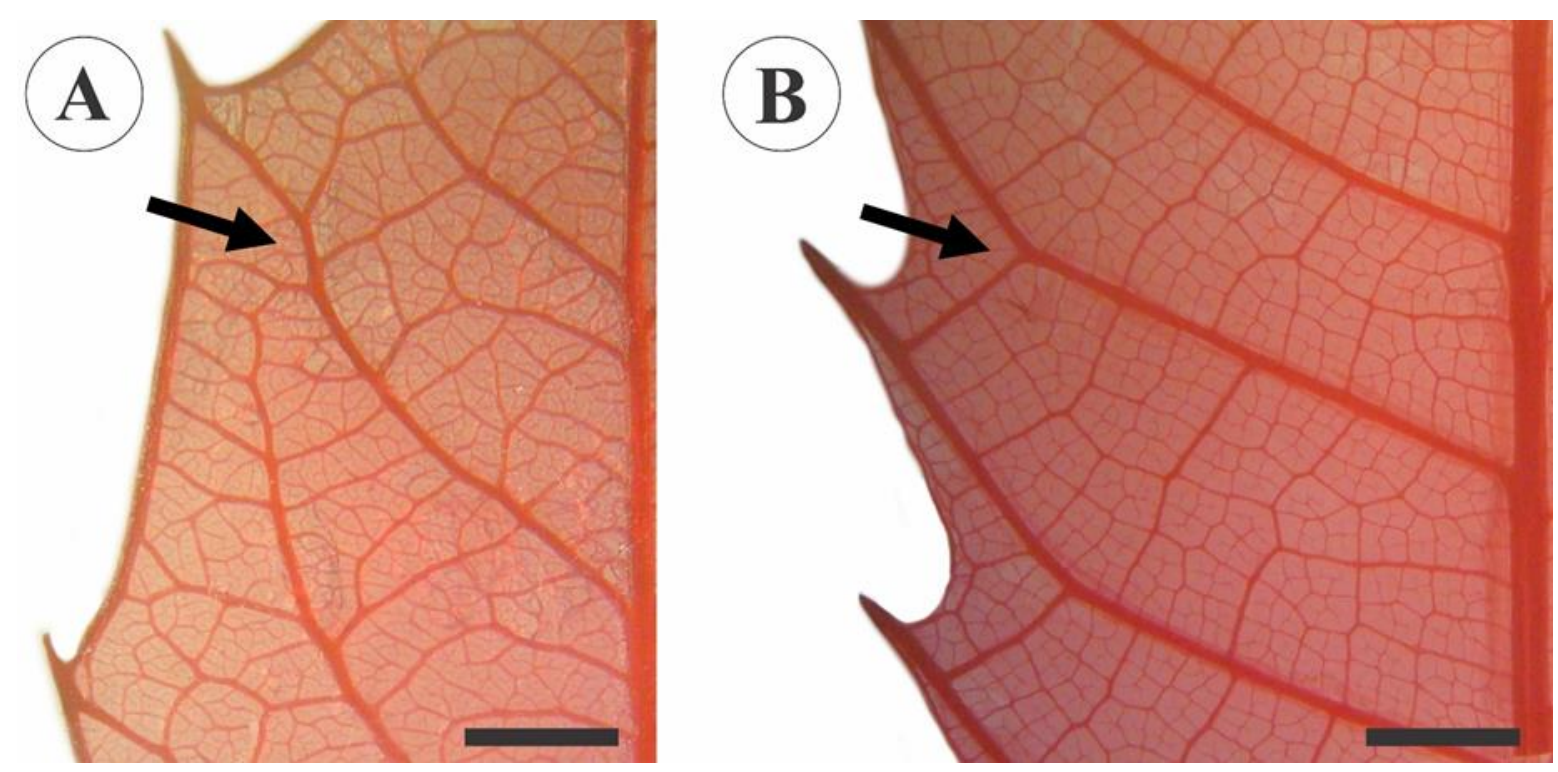

Figure No. 1

Diaphanized leaves of "espinheira-santa" samples, showing the venation patterns. A, Monteverdia ilicifolia. Representative sample from group I. Note the simple craspedodromous pattern (arrow). B, Sorocea bonplandii. Representative sample from group II. Note the semi-craspedodromous pattern (arrow). Bar $=50$ mm

In group I, the petiole's shape was biconvex in cross-section, with the most pronounced curvature on the abaxial surface and two projections facing the adaxial one (Figure No. 2a). The epidermis was uniseriate, glabrous and covered by a thick cuticle with cuticular flanges. The cortex was composed of angular collenchyma and solitary and clustered stone cells. The vascular system was composed of a single amphicribral cylindrical bundle surrounded by a discontinuous fiber sheath (Figure No. 2b). In the midrib region, the leaf blade was biconvex (Figure No. 2c), and its epidermis uniseriate and glabrous, covered by a thick cuticle with cuticular flanges (Figure No. 2d). The subjacent layers were composed of lacunar collenchyma. The vascular system was composed of a single amphicribral flattenedcylindrical bundle surrounded by a discontinuous fiber sheath (Figure No. 2c). 

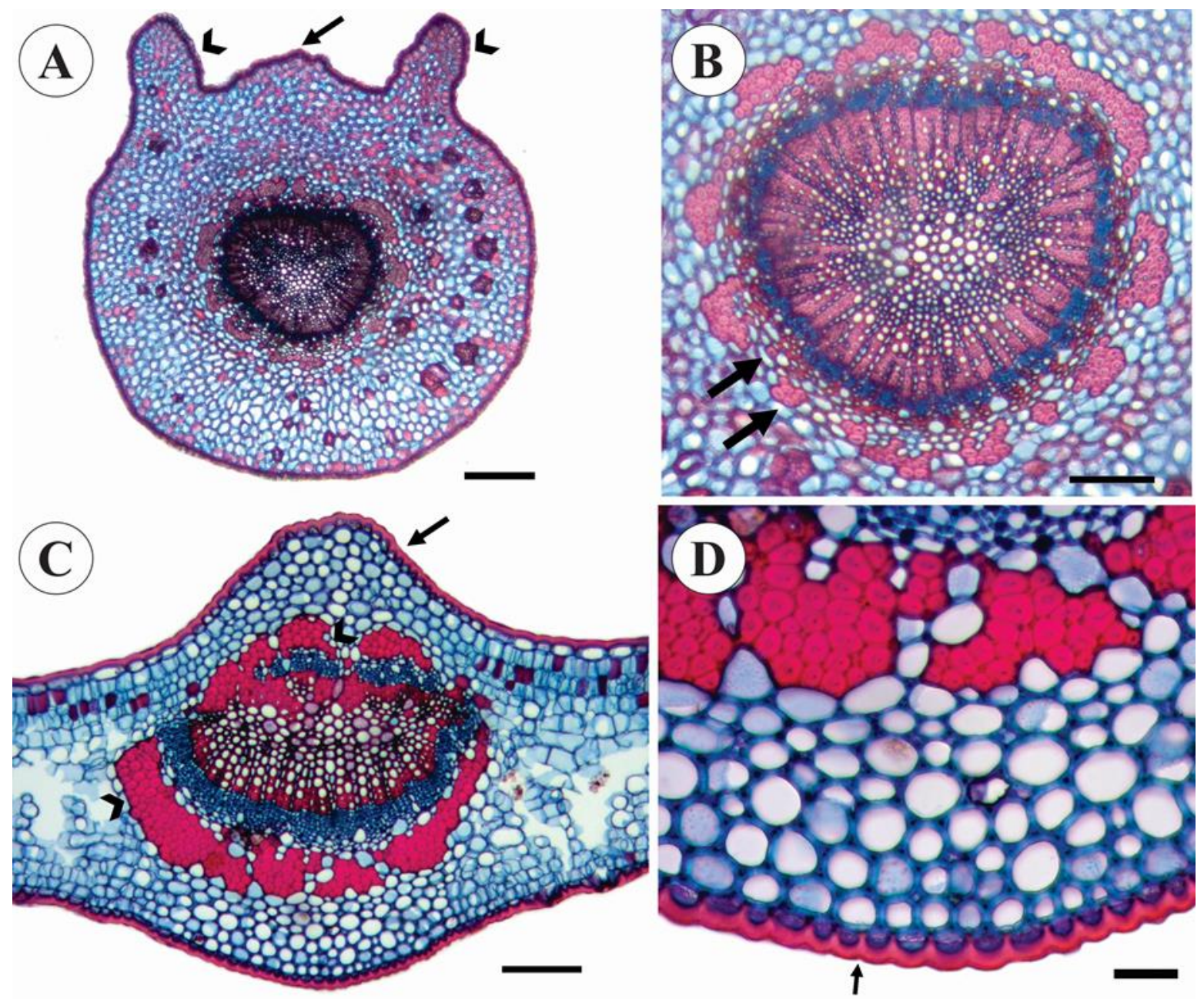

Figure No. 2

Monteverdia ilicifolia. Cross sections of the leaves of "espinheira-santa" samples from group I. A-B, Petiole. A, General aspect. Note the biconvex shape. Arrow = Convex adaxial surface. Arrowheads = Adaxial projections. Bar $=200 \mu \mathrm{m}$. B, Vascular system. Note a single vascular bundle surrounded by a discontinuous fiber sheath (arrows). Bar $=100 \mu \mathrm{m}$. C-D, Midrib region. C, General aspect. Note the biconvex shape. Arrow $=$ Convex adaxial surface. Arrowheads $=$ Discontinuous fiber sheath surrounding the single vascular bundle. Bar $=100 \mu \mathrm{m}$. D, Abaxial surface. Note the glabrous epidermis and cuticular flanges (arrow). Bar $=\mathbf{2 0} \mu \mathrm{m}$

In group II, the petiole's shape was concaveconvex in cross-section and its epidermis uniseriate with glandular and tector trichomes and covered by a thick cuticle (Figure No. 3a). The cortex was composed of angular collenchyma at the peripheral layers and parenchyma at the inner ones, with idioblasts containing druse and prismatic crystals. The vascular system displayed a central collateral bundle apart from other six to ten arranged at a certain distance from one another, composing an arc opened to the adaxial surface (Figure No. 3b). In the midrib region, the adaxial surface was concave and the abaxial sharply convex (Figure No. 3c), the epidermis was uniseriate with glandular and tector trichomes on the abaxial surface and covered by a thin cuticle (Figure No. 3d). The subjacent layers were composed of angular collenchyma with idioblasts containing druses and prismatic crystals. The vascular system was composed of collateral bundles arranged as an arc opened to the adaxial surface where an isolated one could be observed, and surrounded by a discontinuous fiber sheath (Figure No. 3c). 


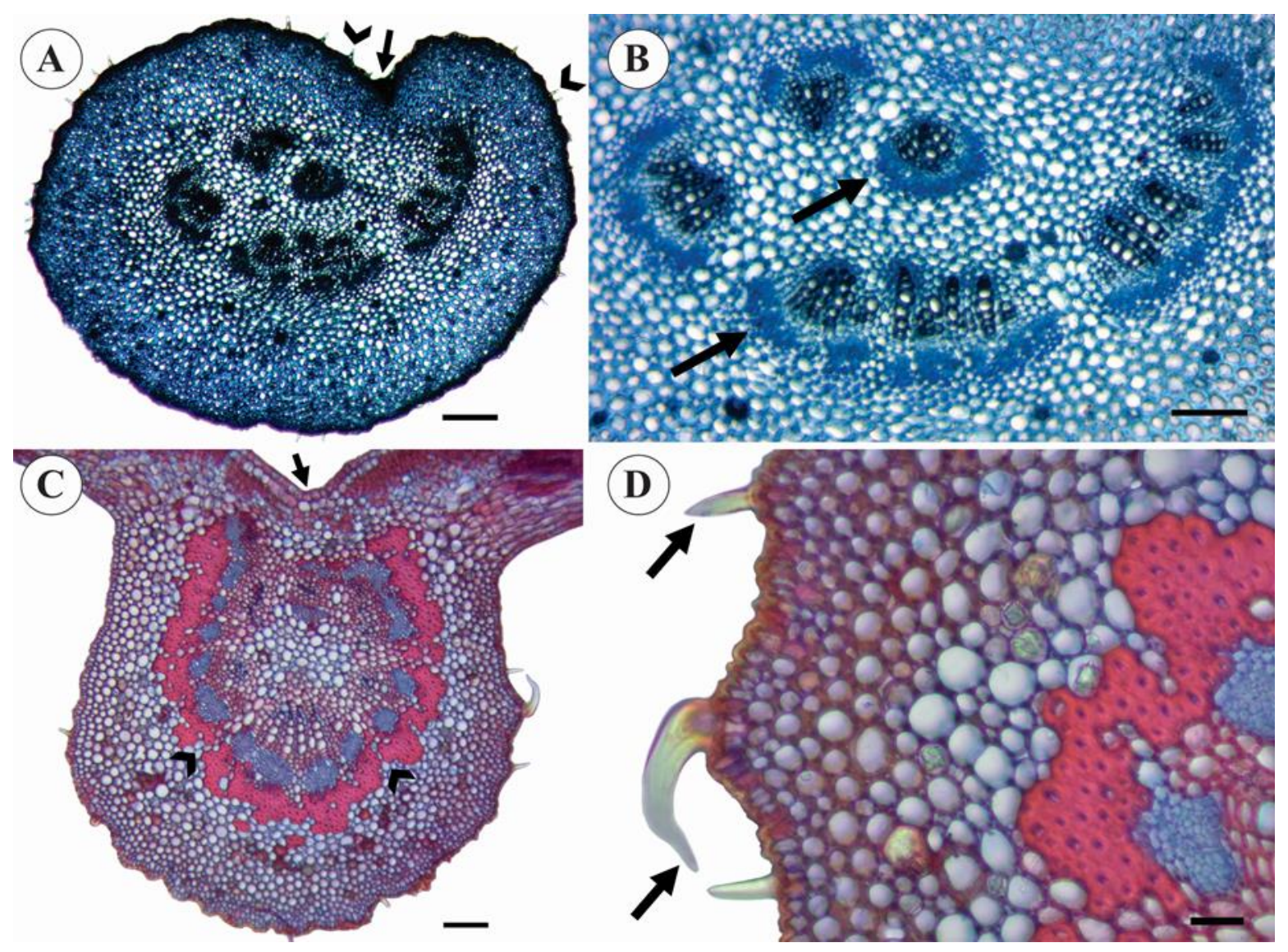

Figure No. 3

Sorocea bonplandii. Cross sections of the leaves of "espinheira-santa" samples from group II. A-B, Petiole. A, General aspect. Note the concave-convex shape. Arrow $=$ Concave adaxial surface. Arrowheads = Trichomes. Bar $=200 \mu \mathrm{m}$. B, Vascular system. Note the presence of multiple vascular bundles (arrows). Bar $=100 \mu \mathrm{m}$. C-D, Midrib region. $\mathrm{C}$, General aspect. Note the concave-convex shape. Arrow $=$ Concave adaxial surface. Arrowheads = Discontinuous fiber sheath surrounding vascular bundles. Bar $=100 \mu \mathrm{m}$. D, Detail of the peripheral region. Note the presence of trichomes (arrows). Bar $=\mathbf{2 0} \mu \mathrm{m}$

\section{DISCUSSION}

The venation pattern constitutes a valuable character for the differentiation of Monteverdia ilicifolia and its adulterants (Machado \& Santos, 2004). The simple craspedodromous pattern observed in group I corresponds to the literature descriptions of $M$. ilicifolia, and the semi-craspedodromous pattern as well as the prominence of the secondary veins in group II corresponds to the description of Sorocea bonplandii (Machado \& Santos, 2004; Brazil, 2019).

Regarding the petiole and leaf blade shapes, the vascular system arrangement and the presence or absence of trichomes in the petiole and midrib regions, the anatomical descriptions of samples in group I are consistent with Monteverdia ilicifolia, and group II with Sorocea bonplandii (Jacomassi \& Machado, 2003; Machado \& Santos, 2004; Brazil, 2019). Furthermore, other anatomical characters are relevant for the diagnosis of $M$. ilicifolia such as the presence of cuticular flanges in the leaf midrib region and a single amphicribral vascular bundle in the petiole and midrib (Duarte \& Debur, 2005) were observed in all samples of group I.

Sorocea bonplandii was one of the most frequent species found in adulterations and falsifications of Monteverdia ilicifolia and the lack of 
studies assuring the absence of chronic toxicity represents a risk for people who inadvertently consume it as "espinheira-santa" (Santos-Oliveira et $a l .$, 2008). The commercialization of $S$. bonplandii is not regulated in Brazil as a medicinal tea (Brazil, 2011), neither as food (Brazil, 2005; Brazil, 2006a). Analgesic and antiulcerogenic activities were demonstrated for leaf extracts of the species, as well as the absence of acute toxicity, but the experiments were performed in mice in a preclinical study (Gonzalez et al., 2001), thus the effective and safe use in humans is not assured by clinical studies. The species substitution in trade may be related to their geographical distribution, considering that $M$. ilicifolia does not occur naturally in Rio de Janeiro state, where $S$. bonplandii is found (Lombardi et al., 2015; Pederneiras et al., 2020).

The Brazilian Policy of Medicinal Plants and Phytotherapeutics highlights the importance of ensuring safety, efficacy and quality in people's access to herbal products (Brazil, 2006b). The companies that produce the phytotherapeutical products would be responsible for carrying out the authenticity analyses, presenting to Anvisa at the notification a technical report for a batch of the medicinal tea, including methods and results of macroscopic and microscopic identification (Brazil, 2014a). The occurrence of falsification in $66 \%$ of the samples evidences that absence or inefficiency of quality control tests or, otherwise, the insufficiency of only one batch required for the authenticity evaluation.

\section{CONCLUSIONS}

In association with the macroscopic morphological analysis, the anatomical study of the leaves demonstrated to be a relevant tool to evaluate the authenticity of "espinheira-santa" commercial samples, suggesting that $66 \%$ were falsifications. The morphological characters used to discriminate Monteverdia ilicifolia from Sorocea bonplandii were the simple craspedodromous venation pattern; the biconvex leaf blade shape in the petiole and midrib regions; the vascular system arrangement in the petiole and midrib, with the presence of a single vascular bundle; fibers surrounding the vascular bundle in the petiole; cuticular flanges in the petiole and midrib; and the glabrous epidermis. Given the falsifications verified in the formal trade and their potential impact on the public health, it is important to emphasize the need for an effective control of medicinal teas.

\section{ACKNOWLEDGEMENTS}

The authors thank Universidade Federal Fluminense for the financial support and for providing infrastructure, material and human resources

\section{REFERENCES}

Aoyama EM, Indriunas A. 2015. Use of anatomy for the identification of vegetal drugs from two species of Justicia (Acanthaceae) marketed as "anador". Sci Plena 11: 1 - 7.

Biral L, Simmons MP, Smidt EC, Tembrock LR, Bolson M, Archer RH, Lombardi JA. 2017. Systematics of new world Maytenus (Celastraceae) and a new delimitation of the genus. Syst Bot 42: 1 - 14. https://doi.org/10.1600/036364417x696456

Brazil. 2005. RDC 267, Anvisa, Brasília, Brazil. http://portal.anvisa.gov.br/documents/10181/2718376/RDC_267_2005_COMP.pdf/cdadfeb0-57c24dc6-910a-ef8c9e3b3bf7

Brazil. 2006a. RDC 219, Anvisa, Brasília, Brazil. http://portal.anvisa.gov.br/documents/33880/2568070/RDC_219_2006.pdf/59ace1c3-a1f8-43e3-81debb3f13a83ad7

Brazil. 2006b. Decree 5813. Approves the Brazilian Policy of Medicinal Plants and Phytotherapeutics and gives other measures. http://www.planalto.gov.br/ccivil_03/_ato2004-2006/2006/decreto/d5813.htm

Brazil. 2009. Brazilian List of Medicinal Plants of Interest to the Public Health System - SUS, Ministry of Health, Brasília. http://portalarquivos2.saude.gov.br/images/pdf/2014/maio/07/renisus.pdf

Brazil. 2011. Form of Phytotherapeutics of the Brazilian Pharmacopeia, Anvisa, Brasília, Brazil. http://portal.anvisa.gov.br/documents/33832/259456/Formulario_de_Fitoterapicos_da_Farmacopeia_ Brasileira.pdf/c76283eb-29f6-4b15-8755-2073e5b4c5bf

Brazil. 2014a. RDC 26, Anvisa, Brasília, Brazil.

http://portal.anvisa.gov.br/documents/10181/3171284/\%282\%29RDC_26_2014_COMP.pdf/a3eae635 -fec3-4936-b836-65e8fe7a8e12 
Brazil. 2014b. Normative Instruction - IN 2, Anvisa, Brasília, Brazil. http://portal.anvisa.gov.br/documents/10181/3295949/IN_02_2014_COMP.pdf/173d7c28-f985-4976b8b5-268d911e997a?version=1.0

Brazil. 2019. Brazilian Pharmacopeia v. 2, $6^{\text {th }}$ ed., Anvisa, Brasília, Brazil. http://portal.anvisa.gov.br/documents/33832/259143/Plantas+medicinais+Pronto.pdf/1b7220eb-a3714ad4-932c-365732a9c1b8

Chimin A, Lima EL, Beltrame FL, Pereira AV, Esmerino LA. 2008. Avaliação da qualidade de amostras comerciais de Maytenus ilicifolia (Espinheira-Santa) comercializadas no Estado do Paraná. Lat Am J Pharm 27: 591 - 597.

Costa RPC, Guimarães ALA, Vieira ACM. 2014. Avaliação da qualidade de amostras de plantas medicinais comercializadas no Brasil. Rev Ciênc Farm Básica Apl 35: 425 - 433.

Coulaud-Cunha S, Oliveira RS, Waissmann W. 2004. Venda livre de Sorocea bomplandii Bailon como Espinheira Santa no município de Rio de Janeiro-RJ. Braz J Pharmacogn 14: 51 - 53. https://doi.org/10.1590/s0102-695x2004000300019

Duarte MR, Debur MC. 2005. Stem and leaf morphoanatomy of Maytenus ilicifolia. Fitoterapia 76: 41 - 49. https://doi.org/10.1016/j.fitote.2004.10.003

Gonzalez FG, Portela EJ, Stipp EJ, Di Stasi LC. 2001. Antiulcerogenic and analgesic effects of Maytenus aquifolium, Sorocea bonplandii and Zolernia ilicifolia. J Ethnopharmacol 77: 41 - 47. https://doi.org/10.1016/s0378-8741(01)00268-9

Hickey LJ. 1973. Classification of the architecture of Dicotyledonous leaves. Am J Bot 60: 17 - 33.

Jacomassi E, Machado SR. 2003. Características anatômicas de espinheira-santa (Maytenus ilicifolia Mart. ex Reissek e Maytenus aquifolia Mart.) e mata-olho (Sorocea bonplandii (Baill.) Burg. Lanj. \& Boer.) para o controle da qualidade da matéria prima. Rev Bras Plant Med 6: 84 - 96. https://doi.org/10.1590/s1516-05722013000200002

Kraus JE, Arduin M. 1997. Manual básico de métodos em morfologia vegetal. EDUR, Seropédica, Brazil.

Leal-Costa MV, Teodoro FS, Barbieri C, Santos LFU, Sousa AL. 2018. Quality assessment of medicinal plants marketed in the Municipal Market of Campos dos Goytacazes-RJ. Fitos 12: 127 - 134.

Leitão F, Fonseca-Kruel VS, Silva IM, Reinert F. 2009. Urban ethnobotany in Petrópolis and Nova Friburgo (Rio de Janeiro, Brazil). Braz J Pharmacogn 19: 333 - 342. https://doi.org/10.1590/s0102-695x2009000200026

Lombardi JA, Groppo M, Biral L. 2015. Celastraceae, in: Lista de espécies da flora do Brasil, Jardim Botânico do Rio de Janeiro. http://floradobrasil.jbrj.gov.br/jabot/floradobrasil/FB6762

Machado AV, Santos M. 2004. Morfo-anatomia foliar comparativa de espécies conhecidas como espinheira-santa: Maytenus ilicifolia (Celastraceae), Sorocea bonplandii (Moraceae) e Zollernia ilicifolia (Leguminosae). Insula Rev Bot 33: 1 - 19.

Pederneiras LC, Ribeiro JELS, Mattos L. 2020. Sorocea in Flora do Brasil 2020 em construção. Jardim Botânico do Rio de Janeiro, Brasil. http://reflora.jbrj.gov.br/reflora/floradobrasil/FB31440

Preto MSM, Tavares MIB, Sebastião PJO, Azeredo RBV. 2013. Determination of herb authenticity by low-field NMR. Food Chem 136: 1272 - 1276. https://doi.org/10.1016/j.foodchem.2012.09.045

Santos MG, Brandes AFN, Joffily A, Ventrella MC. 2015. Coleções Botânicas: laminário, madeiras e frutos. In Santori RT, Santos MG: Ensino de Ciências e Biologia: um manual para elaboração de coleções didáticas. Ed. Interciência, Rio de Janeiro, Brazil.

Santos-Oliveira R, Coulaud-Cunha S, Colaço W. 2008. Revisão da Maytenus ilicifolia Mart. ex Reissek, Celastraceae: Contribuição ao estudo das propriedades farmacológicas. Braz J Pharmacogn 19: 650 - 659. https://doi.org/10.1590/s0102-695x2009000400025

Scheffer MC. 2004. Uso tradicional e atual de espécies de Maytenus. In Reis MS, Silva SR: Conservação e uso sustentável de plantas medicinais e aromáticas: Maytenus spp., espinheira-santa, IBAMA, Brasília, Brazil.

Shobe WR, Lersten NR. 1967. A technique for clearing and staining Gymnosperm leaves. Int J Plant Sci 128: 150 - 152. https://doi.org/10.1086/336391

Teixeira DF, Lucchetti L, Tappin MRR, Cardoso IC, Jacob SDC. 2018. Panorama of Quality of Espinheira-Santa Samples from Local Productive Arrangements and Local Stores of Rio de Janeiro Assayed By Pharmacopoeial Methods And Principal Component Analysis. Rev Virtual Quim 10: 194 - 209. 
https://doi.org/10.21577/1984-6835.20180016

Zhao Z, Hu Y, Liang Z, Yuen JP, Jiang Z, Leung KS. 2006. Authentication is fundamental for standardization of Chinese medicines. Planta Med 72: 865 - 874. https://doi.org/10.1055/s-2006-947209 